\title{
REVIEW OF THE INFLUENCE OF CROP ROTATION AND PRIMARY TILLAGE OPERATIONS ON WEED SEED BANK
}

\author{
Nawal Al-Hajaj ${ }^{1}$ 凹 \\ ${ }^{1}$ Field Crop Directorate, National Center for Agriculture Research, Jordan
}

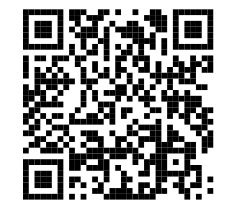

Received 4 July 2021

Accepted 15 July 2021

Published 31 July 2021

Corresponding Author

Nawal Al-Hajaj, Nawal@Narc.Gov.J

o, Nawal_Alhajaj@Hotmail.Com

DOI $10.29121 /$

granthaalayah.v9.i7.2021.4131

Funding: This research received no specific grant from any funding agency in the public, commercial, or not-for-profit sectors.

Copyright: (C) 2021 The Author(s). This is an open access article distributed under the terms of the Creative Commons Attribution License, which permits unrestricted use, distribution, and reproduction in any medium, provided the original author and source are credited.

OPEN

\section{ABSTRACT}

In this study, we reviewed weed seed bank dynamic and main agriculture operations to come up with the weed seed management modeling designed to increase crop productivity by removing weed competition. Weed contributing with $10 \%$ loss of total global grain production. Weed seed bank regulate by five demographic processes seedling recruitment and survival, seed production, dispersal and seed survival in soil. The main agriculture operations that interference with weed seed bank are crop rotation and primary tillage. Tillage systems affect weed emergence, management, and seed production; therefore, changing tillage practices changes the composition, vertical distribution, and density of weed seed bank in agricultural soils. Weed species vary in their response to various crop rotations, due to the variability of weed-crop competition in their relative capacity to capture growth-limiting resources. Crop rotations affect weed emergence, management, composition, and density of weed seed bank. Finally, the study suggests elevating crop competitiveness against weeds, through a combination of crop rotation and reduce_zero tillage, has strong potential to reduce weed-induced yield losses in crop.

Keywords: Weed Seed Bank, Soil Seed Bank, WeedCrop Competition, Tillage, Crop Rotation

\section{INTRODUCTION}

Weed management in field crops is an important aspect for successful crop production. A weed is identified as a plant growing out of place, that is, a plant growing where it is not wanted, or/ better defined as any plant that is objectionable or interferes with the activities or welfare of man. The awareness that weed compete with crops; for sunlight, space, water, nutrients, and threatening native habitats with their role harbor of insects and pathogens; is comparable with probably the domestication of crops and the development of non-nomadic agriculture in agricultural development. Early farmers prepared seed beds to enhance the development of species 
selected as crops, and subsequently removed plants (weeds) that appear with their favored plants. Thus weed management was born to increase productivity by removing competition Anderson (1983). Although plant losses caused by weed interference are "hidden" losses, because farmers cannot detect reductions in productivity due to weeds. Weed losses may be from 5 to $10 \%$ in developed countries, and up to 20 to $30 \%$ in developing countries, specifically the loss 200 million metric tons from $\sim 2.1$ billion metric tons of the global grain production assuming $10 \%$ of overall yield loss due to weeds (www.fao.org/3/a0884e/a0884e.pdf). Weed survey can provide quantitative information about weed community. The composition of weed seed bank that regulates the density of weed population, and the periodicity of germination and emergence of different weed species Buhler (1997), Chauhan and Johnson (2010), are very essential information to establish and implement a successful weed management program Chauhan et al. (2017), Chauhan (2020)

Soil seed bank consists of all viable seeds and propagules present on and in the soil Ma et al. (2021). The species composition and density of weed seed bank in the soil vary greatly and are closely linked to cropping history of the land Nandan et al. (2020). Theoretically, eliminating weed seed bank should be relatively easy. Terminating weed seed production and depleting the seed bank by managing soil to provide optimum environment for germination should be performed (Fig. 1). In practice, managing seed bank is more complex because of the difficulty in preventing seed production and introduction, the continuous persistence of a small percentage of seed bank, and the high seed production potential of many weed species. It is therefore, more realistic to accept weed seed banks as an ever-present component of agricultural lands and attempt to understand, interpret, and predict their behavior. Management systems that attempt to eliminate the seed bank will succeed much more than systems that minimize the impacts of the resultant weeds. Information of the influence of cropping practices on weed seed bank also should be a useful tool in integrated weed management Ball (1992), Schwartz-Lazaro and Copes (2019).

Tillage systems affect weed emergence, management, and seed production; therefore, changing tillage practices changes the composition, vertical distribution, and density of weed seed bank in agricultural soils Buhler (1995), Scherner et al. (2017). Tillage is the primary cause of vertical seed movement in agriculture soils Mohler et al. (2006). Changes in seed depth in soil and corresponding differences in emergence depth may contribute to shifts among weed species under different tillage system due to differences in temperature and light. Temperature differences are expected to enhance seed germination. Light perceived by seeds during soil cultivation is also effective in triggering germination Cordeau et al. (2017). This was confirmed when weed seed emergence following "night tillage" was $80 \%$ lower than emergence under daytime tillage conditions Juroszek et al. (2017).

Crop rotation is an effective tool for weed management Weisberger et al. (2019) by changing the pattern of disturbance, which diversifies selection pressure. This diversification prevents the proliferation of weed species well suited to the practices 


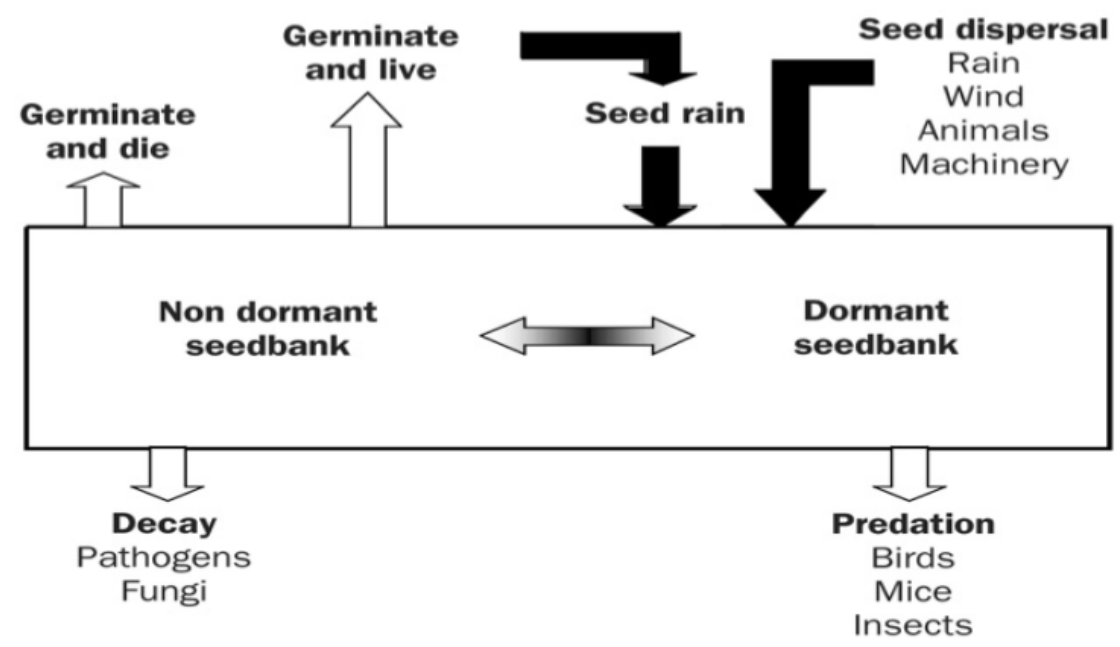

Figure 1 Fateof weed seeds. Inputs to the seed bank are shown with black arrows and losseswith white arrows. [61].

associated with a single crop Buhler, King, et al. (1997). Crop rotations under many field situations decreases weed problems Shahzad et al. (2016). Although moisture conservation is the main objective for most crop-fallow rotations, weed species vary in their response to fallow-rotation. Crop-fallow sequence decreased weed numbers and certain perennial weeds compared to continuous production periods Derksen et al. (1994), H. Z. Ghosheh and Hajaj (2004).

Therefore, the objective of this study is to evaluate the effect and the impact of crop rotation and primary tillage on a weed community that help in control weed management.

\section{WEED SEED BANK CHARACTERIZATION}

Seeds are important for the maintenance and growth of existing weed populations and for the initiation of new populations. An effective production and dispersal mechanism must exist for a weed species to be successful. Seed dispersal can be either through space or through time. The soil seed bank is a useful concept oftenapplied to the dynamics of seed on or in soil, within which soil acts as reservoir of seed with numerous input in and with drawl actions (Figure 1). Soil seed bank, which consist of all viable seeds and propagules present in and on the soil, became a recognized location for imposing weed management practices Radosevich et al. (1997), Geddes and Davis (2021). The seed bank of agriculture weed community may consist of several weed species that differ in density and distribution Fenner (2017). Bio-diversity, which results from taxonomic diversity in traits, such as age structure, dormancy characteristics, longevity, survival, mortality, and germination, is affected by management practices and environmental conditions Fried et al. (2012). 
Weed scientists have recognized that the dynamics of weed seed bank may allow improved weed management strategies Radosevich et al. (1997), Fried et al. (2012). In particular, reducing the size of weed seed bank is gaining considerable attention as a long term-weed management strategy Zwickle (2011). Although, seed production in most weed species can be reduced by management factors, seed production will likely remain great enough to maintain the seed bank with low to moderate weed infestations Chauvel et al. (1989), Schwartz-Lazaro and Copes (2019). In general, five demographic processes regulate the population dynamics of weed seed bank: seedling recruitment and survival, seed production, dispersal and seed survival in soil Kropff and Lotz (1992). The percentage of seed in the soil seed bank that germinate in a given year for common annual species in cultivated soil approximates 1 to $50 \%$ of the seed bank Forcella (1992), Schwartz-Lazaro and Copes (2019), with great variation both within and among species Buhler (1997). The seed bank size in agricultural land ranges from near zero to as much as 1 million seed $/ \mathrm{m}^{2}$ (Witkowski et al. 2000).

Regeneration of plants from seed requires that a portion of the seed are at the right time and are physiologically capable to germination Buhler, Hartzler, and Forcella (1997). Prediction of weed seedling emergence is important to estimate stages of growth and weed interference intensities Bagavathiannan et al. (2020), which aids to determine the precise time of weed management. Light may be a requirement for germination in most weed seed in the soil seed bank Juroszek et al. (2017). Photo conservation of photochrome from the red light (R) absorbing form (Pr) to the far red light (Fr) absorbing form (Pfr), has been identified as part of germination induction mechanism in many plant species Rana et al. (2017). Brief exposures of light are sufficient to promote seedling recruitment Juroszek et al. (2017). In this regard, seed germination and seedling emergence following day time tillage operations was reported to be as much as 60 to $90 \%$ higher than emergence following night tillage operations Gallagher (1996).

Weed scientist have noticed that certain annual species are abundant in some years and less common in others. Explanations for differential abundance from one year to next might include hypotheses such as, annual variation in crop type, time of seedbed tillage, previous year's seed production, herbicide efficacy, pathogen attack, and insect consumption. Another possible explanation involves an "emergence percentage"; the percentage of weed that emerges from seed bank as seedlings each year Schwartz-Lazaro and Copes (2019). Weed emergence time was considered more important than weed density when elucidating crop yield loss Masin et al. (2011). The pattern and magnitude of seedling emergence vary among species due to differences in their response to environment and management factors Humphries et al. (2018). Physical and biological factors, apparent in seed dormancy act as a survival strategy to avoid germination during unfavorable conditions and as a means of dispersal through time Qasem (2019). Moisture, temperature (King and Oliver 1994), light, soil fertility, soil texture and soil disturbance King and Purcell 
(1997), Cordeau et al. (2017), are factors that influence the pattern, survival of seedlings, the growth and productivity of weeds, and thus can affect weeds seed bank and population dynamics Schwartz-Lazaro and Copes (2019).

\section{WEED SEED BANK MANAGEMENT}

Reducing the size of the weed seed bank has been a long-term goal of weed management strategies Sims et al. (2018). Weed surveys canprovide quantitative information about weed communities. This information are very important for; evaluating changes in weed communities over a period of time, for developing integrated weed management programs, and for mapping weed populations Wiles and Schweizer (2002), (Sims et al. 2019). Information such as the relative time of weed emergence in respect of crop emergence Fahad et al. (2015), the nature and severity of crop-weed interference Osipitan (2017), combination of weed-crop density and weed competitiveness Zimdahl (2007), and the critical period of weed control (threshold period), which is that period where it's essential to maintain a weed free environment to prevent yield loss Smitchger et al. (2012), Azimah et al. (2018) are also important. Other biological factors should be considered in weed management plants; such as species competitiveness, seed bank processes and demographic variation Jordan (1992), Zimdahl (2007), weed seed dispersal or spread Jordan (1992), Skarpaas and Shea (2007).Patchiness of an annual weed, defined as ability of weeds to have high dispersal and low competitiveness, cause long term crop yield reduction more than weeds with high competitiveness and low dispersal Hossain and Begum (2015). Patchiness deserves special attention once we know that spared rate rended to increase linearly, while population growth rate increases exponentially Thill and Mallory-Smith (1997). All of the above parameters are very necessary to establish and implement a successful weed management program.

Weed composition in a seed bank reflects past and present weed, crop and soil management practices Liebman et al. (2021), especially those related with tillage Blackshaw et al. (1994), Feledyn-Szewczyk et al. (2020), and crop rotation Ball (1992), Feledyn-Szewczyk et al. (2020), which affect the nature and extent of weed populations Schwartz-Lazaro and Copes (2019). (1992) reported, that tillage (as major soil disturbance) affected population dynamics and annual weed species control, depending on the location of seed in the soil profile Ali et al. (2017). Exposure to many soil factors that differs considerably influence dormancy and viability but grater seed longevity is favored by deep burial Hossain and Begum (2015). The decline of weed seed bank is most rapid for those placed on the surface, whereas the loss in the viability become less with increase depth of seed burial. The buried weed seed are a perpetual concern to agriculturists Omami et al. (1999), Sagona and Mahonya (2018). Information of seed viability and the number of seeds that give rise to seedlings, and the number of seeds that become nonviable influence the magnitude of seed bank depletion Chauvel et al. (1989), Forcella (1992), Fenner 
(2017). In general, cultivation practices affect plant species composition through distributing seed at various soil depths and altering their number Wiles and Schweizer (2002), H. Z. Ghosheh and Hajaj (2004) and composition in the seed bank Clements et al. (1996).

\section{CROP ROTATION}

Crop rotation is defined as the alternation of different crop species on the same land Radosevich et al. (1997), Tanveer et al. (2019). Rotation generally interrupt disease and weed growth cycles and improve soil quality Tanveer et al. (2019), so that its crop yield is improved due to this integral component of sustainable agriculture. For example, barley dry weights and seed yields were 29 and 26\%, respectively, greater in the barley-forage rotation compared with monoculture in all years Stevenson et al. (1998). Weisberger et al. (2019) indicated that crop rotation can have important effects on weed growth through its influence on the competitive ability of the crop. For example, weed species richness and density generally were greater in the barley-forage rotation compared with the monoculture Stevenson et al. (1997). The seed bank of a 3-year continuous corn crop was dominated by one annual grass and two annual broad leaf weed species, whereas 3-year of continues pintobean (Phaseolus vulgaris L.) rotation had a weed seed bank dominated by four annual broad leaf species Ball (1992). A maize (Zea mays L.) wheat rotation was associated with weed communities displaying high evenness, whereas one species comprised 71\% of the individuals in continuous maize Stevenson et al. (1997). As a general rule, the species composition and the density of weed seed on the soil vary greatly and are closely linked to cropping history, and that crop rotation under many field situations decreased weedproblems Shahzad et al. (2016).

The crop-fallow rotations is common in areas with rainfalls below $300 \mathrm{~mm}$ because of the variability of rainfall, where the annual soil moisture supplies are insufficient to sustain adequate growth without a stored soil moisture supply from a previous season. For example, the fallow-wheat rotation had provided stable production with no crop failures when compared with continuous wheat, which failed more than $30 \%$ of the seasons and average water- use efficiency for fallow-wheat was $80 \%$ greater than that for continuous wheat when annual rainfall was between 24.6 and $43.0 \mathrm{~cm}$ Ankeer et al. (1997). The fallow system also provides more flexibility in planting schedules because the seedbed is prepared in the previous spring or summer, depending on the weed control practice during the summer prior to planting Qing and \&amp; hualin (2017). However, recent reports indicated that the reasons for fallowing land may no longer be valid. Fallow is an inefficient method of increasing soil moisture storage, but may be a necessary practice under the arid and semiarid conditions of the brown and dark-brown soil zones Derksen et al. (1994). 
Weed species vary in their response to fallow. Some crop fallow sequences have been found to decrease weed numbers compared to continuous cropping, particularly, number of weeds with short dormancy periods and certain perennial weeds were reduced Baraibar et al. (2017). Fewer weeds were found in winter wheat-fallow cropping systems compared with either continuous winter wheat, winter wheatlentil or winter canola (Brassica napus L.) rotations Blackshaw et al. (1994). Densities of some species, such as common lambsquarters (Chenopodium album L.) and field pennycress (ThlapsiarvenseL.) increases with fallow Hume (1982). The cumulative effects of varied crop competitive abilities, dates of seeding, and weed management practices in crop rotations is to reduce the dominance of specific weeds Aldrich (1984). Certain weeds tend to develop weed-crop associations with certain crops under monoculture cropping, and thus may reach high densities under such condition Derksen et al. (1994), Adeux et al. (2017).

In general, variability in crop response to weed competition under various rotations can be attributed to differences between the crop and the weed species in their relative capacity to capture growth-limiting resources Mc-Donald and Riha (1999), Karimmojeni et al. (2010). The earlier that weeds emerge before the crop, the more likely they are to out compete the crop for light, nutrients, and water FroudWilliams (2002), Cavalieri et al. (2018).

\section{TILLAGE OPERATIONS}

Soil tillage has been a major input of crop production for centuries. While being an integral component of many cropping systems, tillage has negative side effects including increased soil erosion and high labor and fuel requirements Shen et al. (2018). In recent years, herbicides became available to replace tillage for the control of unwanted vegetation Buhler (1995), Ruiz-Colmenero et al. (2011). Nowadays, many definitions exist for tillage operations. Conservation tillage, also known as reduced tillage, is a general term applied on tillage systems that leave at least $30 \%$ of soil surface covered with plant residue after crop harvested and maintains that cover following planting of the succeeding crop Phillips and Phillips (1984), Cogger (2009), Tiessen et al. (2010). This system includes using primary tillage equipment such as chisel plow or disk but without any secondary tillage operations. Conventional tillage refers to systems that leave the soil surface with little plant residue and often include moldboard plowing followed by secondary tillage operations by disks, field cultivators, and/ or harrowing Tiessen et al. (2010). Inquiries into why farmers till the soil usually center around controlling weeds Phillips and Phillips (1984). One of the major reasons why weed management is often difficult, herbicideintensive, and economically costly in tillage is the poor understanding of the relationships between tillage systems and weed population dynamics Nichols et al. (2015). As the impacts of tillage systems on weed population dynamics are examined, we must apply basic ecological principles. Weeds are successful because of their genetic 
diversity, and ability to adapt and take advantage of conditions created by crop production systems. Therefore, modifying crop management inputs will result in an altered competitive environment in which the morphological and physiological traits that confer success will be altered Buhler (1995). Understanding weed population shifts will identify vulnerable stages inweed life cycles that can be exploited in management systems Amare (2016).

Reduced and no or zero tillage systems have replaced conventional tillage by being means of soil conservation, as well as, means of reducing labor, equipment costs and consumption of fossil fuel Sims et al. (2018). Although the potential benefits of reduced tillage are substantial, significant problem remains. Soil temperatures early in the growing season are often reduced, slowing crop emergence and growth Chauhan and Johnson (2010). Reduced tillage also caused shifts in weed species and increased certain weed densities, in addition to increased herbicide use Buchanan et al. (2016) by creating an environment similar to abandoned field Buhler and Own (1997). Conservation tillage minimizes soil disturbance, and thus weeds are expected to display a greater tendency to undergo succession than under conventional tillage Légère et al. (2011). Historically, the greatest obstacle to reduced tillage frequency was to achieve effective, economical, and environmentally sound weed management levels Nichols et al. (2015). However, dependence on the new effective herbicides allowed the adoption of this system, but with noticeable increase in weed control costs under conservation tillage systems Shahzad et al. (2017).

Tillage system may affect weed seed bank dynamics through regulating the plant population and determine the eventual dominant weed species Yenish et al. (1992), Shahzad et al. (2017). This causes both vertical redistribution of weed seed and changes in the soil properties Dorado et al. (1999), Mohler et al. (2006). Tillage systems provide weed seeds with different soil microenvironments due to differences in soil porosity, bulk density and soil surface conditions Gebhardt et al. (1985), Craigmyle (2012). In particular, primary tillage influence the effectiveness of management practices, such as secondary soil disturbance on weed seedling emergence (O'Donvan et al. 1997) Fahad et al. (2015), which causes vertical seed movement in soils Mohler et al. (2006). For example, moldboard plow layer is relatively homogenous in the vertical distribution of seeds within the horizon plowed Dorado et al. (1999). On other hand, chisel plowing has been shown to leave more seeds closer to the soil surface Yenish et al. (1992), Liebman et al. (1996), H. Ghosheh and Hajaj (2005). Clements et al. (1996) reported that more than $60 \%$ of the weed seed bank was concentrated in the upper $5 \mathrm{~cm}$ of soil under chisel plowing, and more viable seeds were present in soil subjected to mould board plowing than chisels plowing H. Ghosheh and Hajaj (2005). In other words, conventional tillage tends to incorporate seeds more uniformly among various soil aggregate classes compared to reduced tillage, and hence, weed seed tends to accumulate in the unaggregated soil surface fraction in reduced tillage Pareja et al. 
(1985), Chauhan and Johnson (2010).

Tillage systems may influence the time of weed seedling emergence Scherner et al. (2017). Differences in soil surface characteristics and disturbance patterns between moldboard plowed and no-tillage production systems influenced seed survival and dormancy, as well as the time and magnitude of emergence H. Ghosheh and Hajaj (2005), Pardo et al. (2019). Some studies have indicated that reduced tillage can result in increases in perennial and some annual weed species Ali et al. (2017), Cordeau et al. (2017), Scherner et al. (2017). In conventional tillage systems, moldboard plowing and secondary tillage just before planting control existing vegetation and help crop seedlings get an equal start with weed seedlings. In conservation tillage systems, especially the no tillage, relative emergence times between crop and weed shift are in favor of the weed Buhler (1995), Scherner et al. (2017). For example, Légère et al. (1997) found, that mid-season barley dry weight was lower and weed dry weight was greater under chisel rather than moldboard plowing, which suggests that crop-weed interference may be more intense in some reduced tillage systems. Although Seipel et al. (2020) found no difference in emergence phenology, the tilled plots had smaller and more diverse communities compared to no-till plots Stevenson et al. (1997), (Fried et al. 2008). Conversely, Légère et al. (2011) reported that weed species diversity would be affected by conservation tillage practices.

The life of weed seed in soil is important because potential weed problems exist as long as weed seed remain viable Nandan et al. (2020). Weed mortality is greater during the seed stage of the life cycle than any other phase Yenish et al. (1992). In this aspect, the "Safe site" is a term that describes the complex conditions that are required for successful seed germination and seedling establishment Radosevich et al. (1997), Jaganathan and Liu (2015) When seeds remain near the soil surface rather than buried in soil, weed seedling emergence and seed bank depletion are grater, due to exposure of more seeds to favorable conditions for germination Gebhardt et al. (1985), Craigmyle (2012). Reduced tillage in this regard, promote shallower weed seed bank more than it increases available "safe site" for emergence or density of small seed weeds Clements et al. (1996) (O’Donvan et al. 1997) Jaganathan and Liu (2015).

Seed burial has been shown to induce dormancy and increase seed survival in some species Menalled (2013), Merino-Martín et al. (2017). Differences in dormancy status may contribute to the large amount of variation that has been found in emergence percentages Menalled (2013), Schwartz-Lazaro and Copes (2019). Temperature differences are expected to enhance seed germination, whereas light perceived by seeds during soil cultivation is also effective in trigging germination Cordeau et al. (2017). This was confirmed when weed seed emergence following "night tillage" was $80 \%$ lower than emergence under daytime tillage conditions Juroszek et al. (2017). H. Ghosheh and Hajaj (2005) stated that absolute germination level in plots cultivated with a chisel plow was too folds or greater than in plots cultivated with 
moldboard plow. The availability of "safe sites" may also determine the temporal/ spatial distribution of seedlings in the field by allowing seed germination in some years at some locations. That explain the special relationship between the distribution of the parent plants and their off springs over the years. The horizontal dispersal of seed with reduced seed inputs at the infested location while increasing distribution to other locations can also be related to "safe site" availability Zhang et al. (1998), Jaganathan and Liu (2015).

The net economic return to weed control was increased $50 \%$ of the time using model recommended treatments compared with standard herbicide treatment Buhler, King, et al. (1997), Price et al. (2018). Weed seed germination and seedling may be modeled empirically or mechanistically (ecophysiologically) Benech-Arnold and Sánchez (2017). Empirical approaches are useful because their analytical simplicity, they are adequate for predicting seed germination and seedling emergence under specific conditions only King and Oliver (1994) because models are not based on the ecophysiology of seed germination Benech-Arnold and Sánchez (2017). The most potential for weed management is the bioeconomic model, which is a potential use of seed bank information in weed management that incorporate seed bank dynamics and prediction of weed emergence into the decision-making process Böcker et al. (2017). A goal of these models is to incorporate weed population dynamics into weed management.

\section{REFERENCES}

Adeux, G., Giuliano, S., Cordeau, S., Savoie, J. M., \& Alletto, L. (2017). Low-Input Maize-Based Cropping Systems Implementing IWM Match Conventional Maize Monoculture Productivity And Weed Control. Agriculture, 7(9), 74-74.

Aldrich, R. J. (1984). Weed-Crop Ecology: Principles In Weed Management. (p. 465). North Scituate, MA: Breton Publishers.

Ali, S., Tahir, M. N., Shah, G. A., Khan, M. A., \& \&amp;mehmood, S. (2017). Dynamics Of Seed Bank And Weed Flora In Rain-Fed Wheat As Affected By Different Tillage Systems. Pakistan Journal of Agricultural Sciences, 54(4), 907-917.

Amare, T. (2016). Review On Impact Of Climate Change On Weed And Their Management. American Journal of Biological And Environmental Statistics, 2(3), 21-27.

Anderson, W. P. (1983). Weed Science Principles. (2nd ed., Vol. 655). St., Paul: West Publishing Company.

Ankeer, A., Battikhi, A. M., \& Khattari, S. K. (1997). Crop Rotations, Tillage Practices, And Frequency Of Nitrogen Fertilizer Applications Effects On Soil Moisture And Crop Yield On A Vertisol In Jordan, Dirasat, Agri. Sci., 24, 224-233.

Azimah, A. K., Ismail, B. S., \& \&amp;juraimi, A. S. (2018). Critical Period For Weed Control In Stevia Rebaudiana (Bert.) Bertoni. Journal of Tropical Agriculture And Food Science, 46(2), 91-98.

Bagavathiannan, M. V., Beckie, H. J., Chantre, G. R., Gonzalez-Andujar, J. L., Leon, R. G., Neve, P., P., ., \& Acker, R. V. (2020). Simulation Models On The Ecology And Management Of Arable Weeds: Structure, Quantitative Insights, And Applications. Agronomy., 10(10), 1611.

Ball, D. A. (1992). Weed Seed Bank Response To Tillage, Herbicides, And Crop Rotation 
Sequence. Weed Sci, 40, 654-659.

Baraibar, B., Canadell, C., Torra, J., Royo-Esnal, A., \& \&amp;recasens, J. (2017). Weed Seed Fate During Summer Fallow: The Importance Of Seed Predation And Seed Burial. Weed Science, 65(4), 515-524.

Benech-Arnold, R. L., \& Sánchez, R. A. (2017). Modeling Weed Seed Germination. Seed Development And Germination, 545-566.

Blackshaw, R. E., Larney, F. O., Lindwall, C. W., \& Kozub, G. C. (1994). Crop Rotation And Tillage Effects On Weed Populations On The Semi-Arid Canadian Prairies. Weed Tech., 8, 231237.

Böcker, T., Britz, W., \& Finger, R. (2017). Bio-Economic Model On Weed Management In Maize Production.

Buchanan, A. L., Kolb, L. N., \& Hooks, C. R. (2016). Can Winter Cover Crops Influence Weed Density And Diversity In A Reduced Tillage Vegetable System. Crop Protection, 90, 916.

Buhler, D. D. (1995). Influence Of Tillage Systems On Weed Population Dynamics And Management In Corn And Soybean Production In The Central USA. Crop Sci, 35, 1247-1257.

Buhler, D. D. (1997). Effects Of Tillage And Light Environment On Emergence Of 13 Annual Weeds. Weed Tech., 11, 496-501.

Buhler, D. D., Hartzler, R. D., \& Forcella, F. (1997). Implications Of Weed Seed Bank Dynamics To Weed Management. Weed Sci, 45, 329-336.

Buhler, D. D., King, R. P., Swinton, S. M., Gunsolus, J. L., , \& Forcella, F. (1997). Field Evaluation Of Abioeconomic Mold For Weed For Weed Management In Soybean (Glycine Max). Weed Sci, 45, 158-165.

Buhler, D. D., \& Own, M. D. K. (1997). Emergence And Survival Of Horseweed (Conyzacanadensis). Weed Sci, 45, 98-101.

Cavalieri, A., Paolini, R., \& \&amp;mirabelli, C. (2018). Yield And Competitive Ability In Potato Cultivars Characterised By Different Developmental Timing. Weed Research, 58(2), 121-130.

Chauhan, B. S. (2020). Grand Challenges In Weed Management. Frontiers In Agronomy, 1, 3-3.

Chauhan, B. S., \& Johnson, D. E. (2010). The Role Of Seed Ecology In Improving Weed Management Strategies In The Tropics. Adv. Agron, 105(10), 5006-5012.

Chauhan, B. S., Matloob, A., Mahajan, G., Aslam, F., Florentine, S. K., \& Jha, P. (2017). Emerging Challenges And Opportunities For Education And Research In Weed. Science. Front. Plant Sci, 8.

Chauvel, B., Gasquez, J., , \& Darmency, H. (1989). Changes Of Weed Seed Bank Parameters According To Species. Time And Environmental. Weed Res, 29, 213-219.

Clements, D. R., Benoit, D. L., Murphy, S. D., \& Swanton, C. J. (1996). Tillage Effects On Weed Seed Return And Seed Bank Composition. Weed Sci, 44, 314-322.

Cogger, M. (2009). Impact Of Conservation Tillage Practices On Weed Management, Soil Properties, And Sweet Corn And Dry Bean Yield And Quality.).

Cordeau, S., Smith, R. G., Gallandt, E. R., Brown, B., Salon, P., Ditommaso, A., \& Ryan, M. R. (2017). Disentangling The Effects Of Tillage Timing And Weather On Weed Community Assembly. Agriculture, 7(8), 66-66.

Craigmyle, B. D. (2012). Influence Of Herbicide Programs, Weed Height, And Glufosinate And 2, 4-D Combinations On Weed Management In Soybean Resistant To 2, 4-D. University Of Missouri-Columbia.

Derksen, D. A., Thomas, A. G., Lafond, G. P., Loeppky, H. A., \& Swanton, C. J. (1994). Impact Of Agronomic Practices On Weed Communities: Fallow Within Tillage System. Weed Sci, 
42, 184-194.

Dorado, T., Delmorte, J. P., \& Lopez-Fando, C. (1999). Weed Seed Bank Response To Crop Rotation And Tillage In Semiarid Agroecosystems. Weed Sci, 47, 67-73.

Fahad, S., Hussain, S., Chauhan, B. S., Saud, S., Wu, C., Hassan, S., Huang, . ., \& J. (2015). Weed Growth And Crop Yield Loss In Wheat As Influenced By Row Spacing And Weed Emergence Times. Crop Protection, 71, 101-108.

Feledyn-Szewczyk, B., Smagacz, J., Kwiatkowski, C. A., Harasim, E., \& \&amp;woźniak, A. (2020). Weed Flora And Soil Seed Bank Composition As Affected By Tillage System In Three-Year Crop Rotation. Agriculture, 10(5), 186-186.

Fenner, M. (2017). Ecology Of Seed Banks. Seed Development And Germination, 507-528.

Forcella, F. (1992). Prediction Of Weed Seedling Densities From Buried Seed Reserves. Weed Res, 32, 29-38.

Forcella, F., Wilson, R. G., Renner, K. A., Dekker, J., Harvey, R. G., Alm, D. A., Buhler, D. D., , \& Cardina, J. (1992). Weed Seed Bank Of The U.S. Corn Belt: Magnitude, Variation, Emergence And Application. Weed Sci, 40, 636-644.

Fried, G., Kazakou, E., \& \&amp;gaba, S. (2012). Trajectories Of Weed Communities Explained By Traits Associated With Species' Response To Management Practices. Agriculture. Ecosystems \& Environment, 158, 147-155.

Froud-Williams, R. J. (2002). Weed Competition. Weed Management Handbook., 9, 16-38.

Gallagher, R. S. (1996). Ecophysiological Aspects Of Phytochrome-Mediated Germination In Soil Seed Banks. Ph. D. Dissertation. The Ohio State University, Wooster, Ohio., 121.

Gebhardt, M. R., Daniel, T. C., Schweizer, E. E., \& Allmaras, R. R. (1985). Conservation Tillage., 230, 625-630.

Geddes, C. M., \& Davis, A. S. (2021). The Critical Period For Weed Seed Control: A Proposed Framework To Limit Weed Seed Return. Weed Research.

Ghosheh, H., \& Hajaj, N. (2005). Weed Seedbank Response To Tillage And Crop Rotation In A Semi-Arid Environment. Soil And Tillage Research, 84(2), 184-191.

Ghosheh, H. Z., \& Hajaj, N. A. (2004). Impact Of Soil Tillage And Crop Rotation On Barley (Hordeum Vulgare) And Weeds In A Semi-Arid Environment. Journal Of Agronomy And Crop Science, 190(6), 374-380.

Hossain, M. M., \& Begum, M. (2015). Soil Weed Seed Bank: Importance And Management For Sustainable Crop Production-A Review. Journal of The Bangladesh Agricultural University, 13(2), 221-228.

Hume, L. (1982). The Long-Term Effects Of Fertilizer Application And Three Rotations On Weed Communities In Wheat After 21-22 Year At Indian Head, Saskatchewan. Can. J. Plant Sci, 62, 741-750.

Humphries, T., Chauhan, B. S., \& Florentine, S. K. (2018). Environmental Factors Effecting The Germination And Seedling Emergence Of Two Populations Of An Aggressive Agricultural Weed. Nassellatrichotoma. Plos One, 13(7), 199491-199491.

Jaganathan, G. K., \& Liu, B. (2015). Role Of Seed Sowing Time And Microclimate On Germination And Seedling Establishment Of Dodonaeaviscosa (Sapindaceae) In A Seasonal Dry Tropical Environment-An Insight Into Restoration Efforts. Botany, 93(1), 23-29.

Jordan, N. (1992). Weed Demography And Population Dynamics Implications For Threshold Management. Weed Tech, 6, 184-190.

Juroszek, P., Neuhoff, D., \& \&amp;köpke, U. (2017). Night-Time Tillage Revisited: The Delayed Soil Desiccation Process In Night-Time Tilled Plots May Promote Unexpected Weed Germination. Weed Research, 57(4), 213-217.

Karimmojeni, H., Mashhadi, H. R., Shahbazi, S., Taab, A., \& \&amp;alizadeh, H. M. (2010). 
Competitive Interaction Between Maize,'Xanthiumstrumarium And Datura Stramonium'Affecting Some Canopy Characteristics. Australian Journal of Crop Science, 4(9), 684-694.

King, C. A., \& Oliver, L. R. (1994). A Model For Predicting Large Crabgrass (Digitariasaguinalis) Emergence As Influenced By Temperature And Water Potential. Weed Sci, 42, 561-567.

King, C. A., \& Purcell, L. C. (1997). Interference Between Hemp Sesbania (Sesbaniaexaltata) And Soybean (Glycine Max) In Response To Irrigation And Nitrogen. Weed Sci, 45, 9197.

Kropff, M. J., \& Lotz, L. A. P. (1992). Systems Approaches To Quantify Crop Weed Interactions And Their Application In Weed Management. Agric. Syst, 40, 265-282.

Légère, A., Samson, N., Rioux, R., Angers, D. A., \& Simard, R. R. (1997). Response Of Spring Barley To Crop Rotation, Conservation Tillage, And Management Intensity. Agron. J, 89, 628-638.

Légère, A., Stevenson, F. C., \& Benoit, D. L. (2011). The Selective Memory Of Weed Seedbanks After 18 Years Of Conservation Tillage. Weed Science, 59(1), 98-106.

Liebman, M., Drummond, F. A., Corson, S., , \& Zhang, J. (1996). Tillage And Rotation Crop Effects On Weed Dynamics In Potato Production Systems. Agron. J, 88, 18-26.

Liebman, M., Nguyen, H. T., Woods, M. M., Hunt, N. D., \& Hill, J. D. (2021). Weed Seedbank Diversity And Sustainability Indicators For Simple And More Diverse Cropping Systems. Weed Research, 61(3), 164-177.

Ma, M., Collins, S. L., Ratajczak, Z., \& Du, G. (2021). Soil Seed Banks, Alternative Stable State Theory, And Ecosystem Resilience. Bioscience.

Masin, R., Vasileiadis, V. P., Loddo, D., Otto, S., \& \&amp;zanin, G. (2011). A Single-Time Survey Method To Predict The Daily Weed Density For Weed Control Decision-Making. Weed Science, 59(2), 270-275.

Mc-Donald, A. J., \& Riha, S. J. (1999). Model Of Crop: Weed Competition Applied To Maize: Abutilon Theophrasti Interactions. II. Assessing The Impact Of Climate: Implications For Economic Thresholds. Weed Res, 39, 371-381.

Menalled, F. D. (2013). Manage The Weed Seed Bank-Minimize "Deposits" And Maximize. Withdrawals". Available At: Extension.Org.

Merino-Martín, L., Courtauld, C., Commander, L., Turner, S., Lewandrowski, W., \& Stevens, J. (2017). Interactions Between Seed Functional Traits And Burial Depth Regulate Germination And Seedling Emergence Under Water Stress In Species From Semi-Arid Environments. Journal of Arid Environments, 147, 25-33.

Mohler, C. L., Frisch, J. C., \& Mcculloch, C. E. (2006). Vertical Movement Of Weed Seed Surrogates By Tillage Implements And Natural Processes. Soil And Tillage Research, 86(1), 110-122.

Nandan, R., Singh, V., Kumar, V., Singh, S. S., Hazra, K. K., Nath, C. P., \&amp;poonia, .., \& P, S. (2020). Viable Weed Seed Density And Diversity In Soil And Crop Productivity Under Conservation Agriculture Practices In Rice-Based Cropping Systems. Crop Protection, 136, 105210-105210.

Nichols, V., Verhulst, N., Cox, R., \& \&amp;govaerts, B. (2015). Weed Dynamics And Conservation Agriculture Principles: A Review. Field Crops Research, 183, 56-68.

Omami, E. N., Haigh, A. M., Medd, R. W., \& Nicol, H. I. (1999). Changes In Germinability, Dormancy And Viability Of Amaranthusretroflexus As Affected By Depth And Duration Of Burial. Weed Res., 39, 345-354.

Osipitan, O. A. (2017). Weed Interference And Control In Cowpea Production: A Review. Journal Of Agricultural Science, 9(12), 11-20. 
Pardo, G., Cirujeda, A., Perea, F., Verdú, A. M. C., Mas, M. T., \& \&amp;urbano, J. M. (2019). Effects Of Reduced And Conventional Tillage On Weed Communities: Results Of A Long-Term Experiment In Southwestern Spain. Planta Daninha, 37-37.

Pareja, M. R., Staniforth, D. W., \& Pareja, G. P. (1985). Distribution Of Weed Seed Among Soil Structural Units. Weed Sci, 33, 182-189.

Phillips, R. E., \& Phillips, S. H. (1984). No- Tillage Agriculture., 3.

Price, A. J., Williams, J. P., Duzy, L. A., Mcelroy, J. S., Guertal, E. A., \& Li, S. (2018). Effects Of Integrated Polyethylene And Cover Crop Mulch, Conservation Tillage, And Herbicide Application On Weed Control, Yield, And Economic Returns In Watermelon. Weed Technology, 32(5), 623-632.

Qasem, J. R. (2019). Weed Seed Dormancy: The Ecophysiology And Survival Strategies. Seed Dormancy And Germination. Intechopen.).

Qing, W., \& \&amp;hualin, X. (2017). A Review And Implication Of Land Fallow System Research. Journal of Resources And Ecology, 8(3), 223-231.

Radosevich, S., Holt, J., \& Ghersa, C. (1997). Weed Ecology For Management. 2nd Ed. Jhon Wiley And Sons,Inc. USA.

Rana, N., Varanasi, A. V., \& Sellers, B. A. (2017). Effect Of Environmental Factors On Weed Germination And Management. Biology, 27-44.

Ruiz-Colmenero, M., Bienes, R., \& Marques, M. J. (2011). Soil And Water Conservation Dilemmas Associated With The Use Of Green Cover In Steep Vineyards. Soil And Tillage Research, 117, 211-223.

Sagona, W., \& Mahonya, S. (2018). 5 Enhancing Household Resilience Through Climate Smart Agriculture In The Lake Chilwa Basin. Socio-Ecological Resilience To Climate Change In A Fragile Ecosystem: The Case Of The Lake Chilwa Basin, Malawi,. (pp. 63-63).

Scherner, A., Melander, B., Jensen, P. K., Kudsk, P., \& Avila, L. A. (2017). Reducing Tillage Intensity Affects The Cumulative Emergence Dynamics Of Annual Grass Weeds In Winter Cereals. Weed Research, 57(5), 314-322.

Schwartz-Lazaro, L. M., \& Copes, J. T. (2019). A Review Of The Soil Seedbank From A Weed Scientists Perspective. Agronomy, 9(7), 369-369.

Seipel, T., Ishaq, S. L., \& \&amp;menalled, F. D. (2020). Weed Communities And Wheat Yield Are Modified By Cropping Systems And Climate Conditions. Biorxiv.

Shahzad, M., Farooq, M., Jabran, K., \& Hussain, M. (2016). Impact Of Different Crop Rotations And Tillage Systems On Weed Infestation And Productivity Of Bread Wheat. Crop Protection, 89, 161-169.

Shahzad, M., Hussain, M., Farooq, M., Farooq, S., Jabran, K., \& Nawaz, A. (2017). Economic Assessment Of Conventional And Conservation Tillage Practices In Different WheatBased Cropping Systems Of Punjab. Pakistan. Environmental Science And Pollution Research, 24(31), 24634-24643.

Shen, Y., Mclaughlin, N., Zhang, X., Xu, M., \& Liang, A. (2018). Effect Of Tillage And Crop Residue On Soil Temperature Following Planting For A Black Soil In Northeast China. Scientific Reports, 8(1), 1-9.

Sims, B., Corsi, S., Gbehounou, G., Kienzle, J., Taguchi, M., \& Friedrich, T. (2018). Sustainable Weed Management For Conservation Agriculture: Options For Smallholder Farmers. Agriculture, 8(8), 118-118.

Skarpaas, O., \& Shea, K. (2007). Dispersal Patterns, Dispersal Mechanisms, And Invasion Wave Speeds For Invasive Thistles. The American Naturalist, 170(3), 421-430.

Smitchger, J. A., Burke, I. C., \& \&amp;yenish, J. P. (2012). The Critical Period Of Weed Control In Lentil (Lens Culinaris) In The Pacific Northwest. Weed Science, 60(1), 81-85. 
Stevenson, F. C., Le'ge're, A., Simard, R. R., Angers, D. A., Pageau, D., , \& Lafond, J. (1997). Weed Species Diversity In Spring Barley Varies With Crop Rotation And Tillage. But Not With Nutrient Source. Weed Sci, 45, 798-806.

Stevenson, F. C., Le'ge're, A., Simard, R. R., Angers, D. A., Pageau, D., , \& Lafond, J. (1998). Manure, Tillage, And Crop Rotation: Effect On Residual Weed Interference In Spring Barley Cropping Systems. Agron. J, 90, 496-504.

Tanveer, A., Ikram, R. M., \& Ali, H. H. (2019). Crop Rotation: Principles And Practices. In Agronomic Crops. (pp. 1-12). Springer.

Thill, C. C., \& Mallory-Smith, C. A. (1997). The Nature And Consequence Of Weed Spread In Cropping Systems. Weed Sci, 45, 337-342.

Tiessen, K. H. D., Elliott, J. A., Yarotski, J., Lobb, D. A., Flaten, D. N., \& \&amp;glozier, N. E. (2010). Conventional And Conservation Tillage: Influence On Seasonal Runoff, Sediment, And Nutrient Losses In The Canadian Prairies. Journal Of Environmental Quality, 39(3), 964980.

Weisberger, D., Nichols, V., \& \&amp;liebman, M. (2019). Does Diversifying Crop Rotations Suppress Weeds? A Meta-Analysis. Plos One, 14(7), 219847-219847.

Wiles, L., \& Schweizer, E. (2002). Spatial Dependence Of Weed Seed Banks And Strategies For Sampling. Weed Science, 50(5), 595-606.

Yenish, J. P., Doll, J. D., \& Buhler, D. D. (1992). Effects Of Tillage On Vertical Distribution And Viability Of Weed Seed In Soil. Weed Sci, 40, 429-433.

Zhang, J., S, A., , \& Hamill. (1998). Temporal And Spatial Distributions Of Velvetleaf Seedlings After 1 Year's Seedling. Weed Sci, 44, 414-418.

Zimdahl, R. L. (2007). Weed-Crop Competition: A Review.

Zwickle, S. L. (2011). Weeds And Organic Weed Management: Investigating Farmer Decisions With A Mental Models Approach (Doctoral Dissertation, The Ohio State University). 